\title{
The identity of Jerieng community in negotiating culture
}

\section{Identitas Orang Jerieng dalam negosiasi budaya}

\author{
Herdiyanti*, Panggio Restu Wilujeng, \& Putra Pratama Saputra \\ Department of Sociology, Faculty of Social and Political Science, Universitas Bangka Belitung \\ Address: Desa Balun Ijuk, Merawang, Bangka, Bangka Belitung Islands 33172 \\ E-mail:vhie_dyan@yaho.co.id
}

\begin{abstract}
Malay identity is the most dominant cultural identity in Bangka Belitung that still holds their strength of local wisdom even though modernization, afforded by tin mining and palm oil exploration, is emerging around them. One of the original Malay people in Bangka Belitung is the Jerieng community. This study is aimed to identify negotiations on the boundaries of the cultural identity of the Jerieng community in West Bangka Regency. This study used the theory of identity building from Manuel Castells and subculture theory. This study also employs a descriptive qualitative approach intended to describe the common symptoms associated with the distribution of Malay culture in the Bangka Belitung Islands Province, especially the Jerieng community. In this study, ten informants were interviewed, consisting of the six elders and four from the younger generation. The locations of this research were Ibul Village, Pelangas Village, and Kundi Village, West Bangka Regency, which was the Jerieng community area. The study results showed that the Jerieng community had a way of maintaining the cultural identity by maintaining the values and norms of their ancestral heritage and harmony between people, the environment, and the natural environment. Meeting with culture outside made the Jerieng community negotiate their identity to form the construction of surviving, changing, identity, and negotiating cultural identity. The Jerieng community's identity was still maintained, including a pilgrimage to sacred tombs, mountain alms, circumcision, and language dialects, while the Jerieng community identity has changed, including village charity, traditional clothing, prayer during the Prophet's birthday, and rituals of spells. Furthermore, the identity of the Jerieng community, including custom clothing and jewelry, language dialects, and the marriage system, is applied through the negotiation process by continuing to carry out some traditions or cultures considered still relevant to people's lives at this time.
\end{abstract}

Keywords: cultural identity; identity negotiation; Malay culture; Jerieng community; subculture

\begin{abstract}
Abstrak
Identitas melayu merupakan identitas kultural dominan di Bangka Belitung yang masih mempertahankan kekuatan kearifan lokal meskipun modernisasi yang dibawa oleh tambang timah dan eksplorasi kebun sawit bermunculan diantara mereka. Salah satu masyarakat melayu asli di Bangka Belitung adalah Orang Jerieng. Penelitian ini bertujuan untuk mengidentifikasi negosiasi batas-batas identitas budaya Orang Jerieng di Kabupaten Bangka Barat. Penelitian ini menggunakan teori bangunan identitas dari Manuel Castells dan teori subkultur. Penelitian ini menggunakan pendekatan kualitatif deskriptif yang bermaksud untuk memberikan uraian mengenai gejala-gejala sosial yang berkaitan dengan persebaran kebudayan Melayu di Provinsi Kepulauan Bangka Belitung, khususnya Orang Jerieng. Di dalam penelitian ini ada sepuluh informan yang diwawancarai. Lokasi penelitian ini adalah Desa Ibul, Desa Pelangas, dan Desa Kundi, Kabupaten Bangka Barat yang merupakan wilayah Orang Jerieng. Hasil penelitian menunjukkan bahwa Orang Jerieng memiliki cara tersendiri dalam mempertahankan identitas budaya yang mereka miliki dengan memelihara nilai dan norma warisan leluhur, keharmonisan antar masyarakat, lingkungan, serta alam sekitar. Pertemuan dengan budaya di luar membuat orang-orang Jerieng menegosiasiskan identitasnya sehingga membentuk bangunan identitas yang bertahan, yang berubah, dan identitas budaya yang bernegosiasi. Identitas Orang Jerieng yang masih dipertahankan, diantaranya ziarah makam keramat, sedekah gunung, sunatan, dan dialek bahasa. Sedangkan identitas Orang Jerieng yang mengalami perubahan, diantaranya sedekah kampung, pakaian tradisional, sholawatan saat maulid nabi, dan ritual mantra-mantra. Selanjutnya, identitas Orang Jerieng yang melalui proses negosiasi, diantaranya pakaian dan perhiasan adat, dialek bahasa, serta sistem pernikahan.
\end{abstract}

Kata Kunci: budaya Melayu; identitas budaya; negosiasi identitas; Orang Jerieng; subkultur 


\section{Introduction}

This article contains a study of identifying a cultural identity that is predominant in Malay culture. The cultural identity studied in this study is the Malay identity of Orang Jerieng (Orang means to call for Jerieng people based on their Malay subculture ethnicity) hereafter referred to as the Jerieng community in West Bangka. There have been many studies about Bangka society and culture that examined the Jerieng community, and most of them explain that Malay cultural identity is close to Islamic culture (Elvian 2009, Heidhues 1992, Nukraheni et al. 2019, Reid 2015, Syaifuddin 2019, Sunandar 2015, Thamrin 2015, Zami 2019). Malay culture is all about creation, taste, intention, and the Malay people. Cholid (2019) states that Bangka Malay, the most ethnic group (majority) on the island of Bangka, has a reasonably stable share in creating harmony. This harmony does not necessarily form on its own, and there are many contributing factors so that Bangka people can live in harmony in diversity, one of which is local wisdom possessed by the Malay people of Bangka. Local wisdom can become social capital as a glue of integration in avoiding conflict between ethnics.

Negotiation is one form of communication in order to reach an agreement or agreement between two or more parties. In the international context and scope with a variety of cultural diversity, proper management in negotiations is needed. Success in negotiation is determined by the ability of the negotiator to recognize and to position themselves with related cultures, so analysis and formation of strategies are needed to realize the best agreement for both parties (Alavoine 2014). If it is drawn from its history, Malay culture derives from a culture owned by Malays or the Austronesian Nations. Malays or Austronesian people spread in Southeast Asia, such as Indonesia, Malaysia, Singapore, Thailand, Vietnam, Philippines, and Brunei. According to Fischer (1980), the spread of people in Southeast Asia was caused by several factors, namely the migration of the Austronesian Nation, after which this nation lived on different islands. After being separated, the Austronesian people rarely communicated among themselves.

Bangka Belitung Islands Province is an area that has several types of people, including Lom, Sekak, Jerieng, Darat, Bugis, Javanese, Minang, Batak, and Chinese. Among these people, Malays are the most dominant. It can be seen from the lives of the people who are still very thick with Malay culture. One of the Malays who still maintain their wavering identity is the Jerieng community. Usually, they are better known as Orang Jerieng. The majority of the Jerieng community is in the Simpang Teritip Subdistrict, West Bangka Regency, in Ibul Village, Pelangas Village, and Kundi Village. In general, the Jerieng community adheres to Islam, and the livelihood of its people is as farmers (Bahridi 2010). Jerieng community still cling to the customs inherited from their ancestors; these include the law of exile, body, fines, betian in uten, bekelai, munoh, dan buyong (free sex, fight, murder, and incest).

Jerieng community retains its custom to maintain harmony between the people, the environment, and the surrounding environment. One of the efforts made in preserving the customs that have been possessed by the Jerieng community is to hold a traditional party every year. The custom party is aimed at preserving the cultural identity which has been owned by the Jerieng community. The ethnic Bangka Malays do not feel threatened by the arrival of ethnic groups from other islands because they feel the same fate, and that makes the outside ethnic feel valued and accepted until a harmonious interaction exists between them (Cholid 2019). The efforts made by the Jerieng community in maintaining cultural identity in the era of globalization are very rapidly propagating all aspects of people's lives. A community effort in negotiating with the onslaught of globalization means maintaining the boundaries of the Jerieng community's cultural identity. Therefore, the intervention of modernization will certainly not be avoided by the Jerieng community. This condition has attracted the attention of researchers to examine the negotiation of the boundaries of Jerieng community identity.

Negotiating the boundaries of cultural identity carried out by the Jerieng community is an effort made in the process of assimilation and acculturation; this can consist of acceptance and fraction of the new culture and can result in changes, or even old cultures can survive, such as language, mass 
circumcision, and others, among immigrant communities and the Jerieng community indigenous people. Negotiations on the outside culture that enter into the Jerieng community are actions to deal with existing differences. According to Haikkola (2011), identities are negotiated in the intersection of multi-ethnic realities of every day involving multiple ethnic hierarchies.

It is known that modernization and globalization are used as access that can affect change in all aspects of people's lives. It becomes interesting when during conditions of modernization and globalization, the existence of the Jerieng community at any time will obtain a threat in the preservation of Malay culture that is owned by the local community. This study seeks to link the phenomenon of the Jerieng community experience by using one of the cultural theories regarding identity and subculture. Subculture theory is one of the theories that is considered relevant for studying this research because it sees people in the Jerieng community as a community under the Malay culture of Malay. This theory raises an attempt to see collective experience and memory arising from the contradictions of various social structures. Subculture builds a form of collective identity where individual identities can be obtained beyond the level of identity in class, education, and work. Subculture is constitutional for the object of its study because the unit of analysis contains culture inside the dominant culture- subculture becomes most often tied either to the study of religious and ethnic enclaves (Williams \& Hannerz 2014). The subculture concept can explain how the Jerieng community Malay subculture identity has a dynamic movement that bonds in their Malay-dominant identity culture. The subculture can be identified by symbols such as language or customs. This theory is used to see Jerieng community identity construction that survives as a representation of Malay culture, the primary culture of the Jerieng community.

In addition to using subculture theory, this study also uses the identity-building theory of Castells (2010a). Castells (2010a) argues that identity is built on three forms, legitimizing identity, identity resistance, and project identity. A maintained identity will build a project identity, a new identity, which will eventually dominate social institutions, then form a legitimizing identity to rationalize that dominance, such as civil society, for example, as a form of democracy from social change. Identity resistance forms a community, and project identity transforms individuals to become 'subject.' Legitimizing identity is formed by institutions that are dominant in society that rationalize their dominance when facing (vis a vis) with actors related to authority, domination, and nationalism. According to Castells (2010a), resistance identity is formed when the position or condition of an actor loses value and is stigmatized by the logic of domination, builds a defense, and saves a different base of principles from the institution of society and raises identity politics. Lastly is projecting identity where actors build identity when material culture is available to reinterpret their position in society. Construction identity is like a material building, where the identity of a person or group is built by history, geography, production biology, and institutional reproduction, collective memory and personal, state fantasy and belief in God (Castells 2010a, 2010b, Castells 2011).

Castells $(2010 \mathrm{a}, 2010 \mathrm{~b})$ seeks to offer the right implications for his analysis of how identity is constructed in building a collective identity and its relevance from several processes of social change in community networks. The implication arises from the process of negotiating an identity that meets with cultural identities outside it. This study has relevant correlations between the theories used in analyzing the lives of the Jerieng community. The life of the Jerieng community has a distinctive cultural characteristic, however, amid its distinctiveness, the Jerieng community also negotiates identity with the cultures outside of them.

\section{Research Method}

This study uses a descriptive qualitative approach to describe the common symptoms associated with the distribution of Malay culture in the Bangka Belitung Islands Province, especially the Jerieng community. The researcher described a symptom based on the indicators that used as the basis for the presence or absence of symptoms, which were then examined by using interpretive measures as the basis of the assessment. The approach in this study used interpretive sociology (verstehen), 
which is explained by Weber as a segment where humans give meaning to the social world and the surrounding culture, focused on meaning rather than measurement (Ritzer 2009, Sherman \& Reid 1994). Interpretive sociology emerging based on social life phenomenon from subjective, systematically. The study explains how people make sense and interpret their social world, actions, and identities (Adorjan \& Kelly 2016).

The locations of this research were Ibul Village, Pelangas Village, and Kundi Village, West Bangka Regency, a Jerieng community area. The reason for researching that location or region was because of their uniqueness. The Jerieng community has a dialect of the language, customs, culture, social system, and a belief in custom, which is higher than that of religious belief. The data used to support this research were in-depth interviews, participatory observation, literature, and document studies. Documents, as well as texts, are relevant to the research conducted. Data collection techniques in this study were observations of the culture and behavior of the Jerieng community group.Researchers also collected data from documents related to the research in the form of history and development of Malay culture.

In this study, the sampling technique used was non-probability sampling and purposeful sampling, where the opportunity for informants to be interviewed is not the same. It is because the basis of sampling is based on the informants' knowledge to describe the identity of the social group or group culture where they live together. In addition, the selection of informants was based on people who were considered to know the condition of the Jerieng community. This study interviewed ten people comprising of six Jerieng community elders, two of them from Customary Institution or Lembaga Adat Orang Jerieng, and the other four are the younger generation. Informants were obtained by visiting their houses door-to-door. We found the informants' location based on information from the elders of the customary institution, and research in the field was completed in two months.

\section{Results and Discussion}

The Jerieng community Malay tribe is one of the tribes in the Bangka Belitung Islands. The Jerieng community is currently scattered in several villages in West Bangka Regency, including Berang Village, Pelangas Village, Rajab Village, Belar Village, and Ibul Village. The Jerieng community tribe is a tribe that has unique characteristics that are different from those of other tribes in the Province of Bangka Belitung Islands. The unique and original cultural distinctiveness of each inland tribe means the community must be able to maintain its cultural identity. However, often, cultural identity changes due to the factors and effects of modernization and globalization. It is also called the phenomenon of assimilation and acculturation, which are two of the concepts known when someone talks about an interethnic or interaction relationship and communication between two communities or individuals of different cultures.

Experts and scientists do not uniformly interpret the concepts of acculturation and assimilation. Acculturation and assimilation influence the different behavior; the former refers to the behavior of a person or persons from the non-dominant group, and the latter refers to the behavior of the dominant group. The relation of identity and acculturation takes place at both the psychological and sociological level. At the psychological level, changes in language, behavior, values, beliefs, and norms present within the individual, whereas, at the sociological level, these changes present at the group and institutional levels. Acculturative processes or outcomes are often measured using identity and identification (Adams \& van de Vijver 2017, Marhayati \& Suryanto 2017). Between them, they give various resolution and meaning, the efforts of the West Bangka Regency government passed Regional Regulation No.4 of 2013 concerning the preservation of custom. However, the strong currents of modernization, such as government programs, the entry of the oil palm industry, modern Islamic culture, and urbanization, still make the Malay cultural identity of the Jerieng community eroded.

\section{The livelihood of the Jerieng community}

Until now, the Jerieng community tribe has a livelihood in the agricultural sector, only experiencing changes in the commodity sector. It was marked by the change in the commodity-producing rice 
and pepper, however, now it has turned into commodity-producing palm oil. The belief held by the Jerieng community, in general, is Islam, which has more or less influenced their culture and traditions. Many of the values of Islam that the Jerieng community embrace, such as being humble, should not be jealous of others' success, may not deteriorate, may not persecute others, have formed into a typical value of the Jerieng community who mix with Islam.

\section{The typical of language}

In interacting with everyday people, the Jerieng community uses a distinctive language dialect, among other tribes in the Bangka Belitung Islands, wherein it is one of the ways to identify the Jerieng community tribe. In addition, the language is also a bond between other members of the Jerieng community because they consider that, in using the Jerieng community language dialect, they will develop a sense of togetherness when they use it outside the region. Although the language dialect is one of the foundations of the Jerieng community identity, it is also changing due to the contamination of other languages. Hence, the Jerieng community, especially the young people, no longer uses the original Jerieng community dialect. It is appropriate for the general public to have culture as a characteristic. The Jerieng community also have a culture, where the culture from traditions has been carried out for generations and forms an identity that distinguishes the Jerieng community people from other tribes in the Bangka Belitung Islands.

\section{Jerieng community tribal culture}

Based on the history of the Jerieng community, the people have produced cultures that became the identity of the Jerieng community tribe itself. The classification of culture, which is the identity of the Jerieng community, is as follows: 1) alms village, 2) alms mountain, 3) pilgrimage of sacred tomb (bakek), 4) Jerieng language, 5) Prophet's birthday, 6) final Al-Qur'an, 7) circumcision, and 8) dambus (musical instrument). Among these cultural classifications forming the identity of the Jerieng community, several cultures have begun to change, and some cultures remain survived into a strong identity in the Jerieng community tribe. There are several findings of the dynamics of the transition of the Jerieng community identity. Over time, the meeting of the Jerieng community groups with various forms of community and a new culture has influenced the process of legitimacy, negotiation, and transition from their identity.

Table 1.

Jerieng community identity negotiations

\begin{tabular}{ccc}
\hline Surviving identity & Identity negotiation & Changing identity \\
\hline Sacred tomb pilgrimage & Custom clothing and jewelry & Alms village \\
Alms mountain & Language dialects & Traditional cloth \\
Circumcision & Marriage system & Prayer during the Prophet's birthday \\
Language dialects & - & Prophet's birthday rituals of spell \\
\hline \multicolumn{2}{c}{ Source: Processed by researchers }
\end{tabular}

\section{Jerieng community and colonial history}

There are several findings of the dynamics of the transition of the Jerieng community identity. Over time, the meeting of the Jerieng community groups with various forms of community and a new culture has influenced the process of legitimacy, negotiation, and transition from their identity. Research among the older generation of the Jerieng community explained that Dutch colonialism gave a collective memory to the Jerieng community. Collective memory is a representation of the past of a group that gives substance to the group's identity and current conditions and determines their perspective on the future (Misztal 2003). Collective memory can be constructed and passed down to the next generation in the group. The experience of the history of the older generation and the construction of the Jerieng community identity of its predecessor-generation formed a collective awareness that was internalized into the Jerieng community members. The development of a society 
based on this diversity makes it difficult for us to understand the community. The difficulty arises because the reality of society is already integrated with the understanding, though, and nature that forms the most profound consciousness. Understanding that then forms a reality of cultural society, which becomes a habit that is not realized collectively- the collective unconsciousness (Iwanebel 2016).

The historical experience that made the Jerieng community as the heirs of the Majapahit Kingdom who participated in fighting against colonialism strengthened the construction or the foundation of the legitimacy of the Jerieng community identity. Identity construction through this collective memory experience then makes the Jerieng community identity survive. Reid (2009) explains the colonial influence in Southeast Asia in shaping community identity. The journey of history then proves how the social world of society is built and becomes the national or national identity attached to the population in the region. The meeting with the colonials constructed the history of the Jerieng community through the old generation even though these stories were not passed on to the next generation.

\section{Traditional Jerieng community institutions}

If it is associated with the concept of identity according to Tajfel and Jenkins in Hornung (2019) about the social identities in the policy process in the form of identity of the Jerieng community is the institutional order, which is an identity formed from the pattern of group organization that they have, where there is always a distinction between individuals who are not part of which group. Communities within the West Bangka community identify their group's identity as the Jerieng community. The identification of group identity formation is organized and maintained through customary institutions. This Jerieng community customary society then forms the legitimacy of the Jerieng community identity in the community. All forms of customs, traditions, language, and culture of the Jerieng community are inherent, enduring, bound, and institutionalized under the adat institution. The existence of this customary institution ensures the identity of the Jerieng community persists.

Based on Jenkins' thinking in Hornung (2019), members of the community within the Jerieng community negotiate their identities to be interpreted by the surrounding community based on the organizational boundaries of identity that unite them. Jenkins in Hornung (2019), explained that the meaning of the outside community also legitimized the identity of the Jerieng community who negotiated their identity. One form of the legitimacy of the identity expressed by the Jerieng community is through their cultural symbols, namely language and tradition. In addition, one of the legitimacy of space symbols that still materially survive is shown through the Malay traditional house of the Jerieng community. According to the legitimacy of identity, the Jerieng community survives through traditional, territorial, and cultural symbols that the community recognizes, which are then institutionalized and legally recognized.

\section{Interplay and contestation of Jerieng's community identity}

Castells (2010a) stated that the building of identity is based on the actor who constructs, namely, legitimizing identity, identity resistance, and project identity. The maintained identity will build a project identity, with its cultural resources to obtain its position back in the community. Then, a new identity that is accepted by the community over time will dominate and rationalize social institutions to form a legitimizing identity to rationalize such dominance, for example, social movements or a civil society formed in the democratic space of social change. The third is identity resistance, wherein identity forms a community that opposes the dominant identity (Castells 2010a).

This Jerieng community identity is included as a project identity that is contested with other dominant identities. The identity of the Jerieng community people is being transformed because of assimilation and acculturation among the Jerieng community with people outside the Jerieng community through marriage and also interactions with other communities who live near Jerieng community settlements. Jenkins calls this form of contestation as an interplay or identity negotiation; how the identity negotiates the identity, they have with another identity. 


\section{Conclusion}

The identity of the Jerieng community still survives through language, symbols, preserved traditions such as sacred tomb pilgrimages, mountain alms, sunnatan, and language dialects and traditional institutions. However, in the process, the Jerieng community has transformed and negotiated with modern cultures, such as dress, adopting modern technologies, building houses, and population administration systems. The Jerieng community people also transformed into workers, which involved them in modern institutions. The legitimacy of the Jerieng community has experienced obscurity within certain limits, because of the history of the origins of people whose authenticity cannot be ascertained. Then, the breakdown of the chain of construction of identity from the old generation to the younger generation has caused many of these identities to lose their authenticity as a whole local identity. The study results indicate that the Jerieng community identity survives within certain boundaries, which then continue to negotiate with new identities, gradually losing much of the authenticity of its identity to encourage the identity of this person to negotiate and transform into a new Jerieng community identity.

\section{References}

Adams BG \& van de Vijver FJR (2017) Identity and acculturation: The case for Africa. Journal of Psychology in Africa 27 (2):115-121. https://doi.org/10.1080/14330237.2017.1301699.

Adorjan M \& Kelly B (2016). Interpretive sociology. Encyclopedia of Sociology 2:1-5. https://doi. org/10.1002/9781405165518.wbeos0698.

Alavoine C (2014) Teaching (and learning) negotiation: Is there still room for innovation? International Journal of Management \& Information Systems 18 (2):35-40. https://doi. org/10.19030/ijmis.v18i1.8337.

Bahridi (2010) Sanksi hukum dalam perkawinan Suku Melayu Jerieng di Kecamatan Simpang Teritip Bangka perspektif hukum Islam. Skripsi, Universitas Islam Negeri Sultan Syarif Kasim, Riau.

Castells M (2010a) The Power of Identity (2nd Ed). New Jersey: Wiley-Blackwell.

Castells M (2010b) Globalization and identity. Quaderns de la Mediterrània 14: 89-98.

Castells M (2011) A network theory of power. International Journal of Communication 5:773-787.

Cholid N (2019) Nilai-nilai moral dalam kearifan lokal budaya Melayu Bangka dan implikasinya terhadap layanan bimbingan dan konseling masyarakat. Scientia: Jurnal Hasil Penelitian 4 (2):329-351.

Elvian A (2009) Organisasi Sosial Suku Bangsa Melayu Bangka. Bangka: Franita.

Fischer G (1980) Pengantar Antropologi Kebudayaan Indonesia. Jakarta Pembangunan.

Haikkola L (2011) Transnational and local negotiations of identity: Experiences from secondgeneration young people in Finland. Nordic Journal of Migration Research (NJMR) 1 (3):156-165. https://doi.org/10.2478/v10202-011-0019-8.

Heidhues MFS (1992) Bangka Tin and Mentok Pepper: Chinese Settlement on an Indonesian Island (Social Issues in Southeast Asia). Singapore: Institute of Southeast Asian Studies.

Hornung J, Bandelow NC, \& Vogeler CS (2019) Social identities in the policy process. Policy Sciences 52:211-231. https://doi.org/10.1007/s11077-018-9340-6.

Iwanebel FY (2016) Bhikhu Parekh critics toward modern pluralism. TEOSOFIA: Indonesian Journal of Islamic Mysticism 5 (2):103-114. http://doi.org/10.21580/tos.v5i2.1722.

Marhayati N \& Suryanto (2017) The acculturation strategy of the tabut community in Bengkulu. Studia Islamika 24 (3):403-433. http://doi.org/10.15408/sdi.v24i3.4319.

Misztal BA (2003) Durkheim on collective memory. Journal of Classical Sociology 3 (2):123-143. https://doi.org/10.1177\%2F1468795X030032002. 
Nukraheni Y, Afriansyah B, \& Ihsan M (2019) The ethnozoology of jering ethnic society in utilizing the animals for halal traditional medicine. Journal of Halal Product and Research 2 (2):6067. http://dx.doi.org/10.20473/jhpr.vol.2-issue.2.60-67.

Reid A (2009) Imperial Alchemy: Nationalism and Political Identity in Southeast Asia. Cambridge: Cambridge University Press.

Reid A (2015) Religious pluralism or conformity in Southeast Asia's cultural legacy. Studia Islamika 22 (3):387-404. http://doi.org/10.15408/sdi.v22i3.2352.

Ritzer G (2009) Teori Sosiologi: Dari Teori Klasik Sampai Perkembangan Mutakhir Postmodernisme. Yogyakarta: Kreasi Wacana.

Sherman E \& Reid WJ (1994) Qualitative research in social work. New York: Columbia University Press.

Sunandar (2015) Melayu dalam tantangan globalisasi: Refleksi sejarah dan berubahnya sistem referensi budaya. KHATULISTIWA: Journal of Islamic Studies 5 (1):60-73.

Syaifuddin W (2019) Literary tradition of the sea in Malay Society on the east coast of North Sumatera as behavior guidance in preventing disaster. In: The 28th International Conference in Literature XXVIII, 11-13 April 2019, Banda Aceh.

Thamrin H (2015) Enkulturisasi dalam Kebudayaan Melayu. Al-Fikra: Jurnal Ilmiah Keislaman 14 (1):98-151.

Williams P \& Hannerz E (2014) Articulating the "Counter" in Subculture Studies. Journal Media Culture 17 (6).

Zami R (2019) Orang Melayu pasti Islam: Analisis perkembangan Adat Melayu. Jurnal Islamika Volume 2 (1):66-81. 